\title{
ANALISIS COMMENTS TO SUBSCRIBER RATIO YOUTUBE PADA 10 YOUTUBER INDONESIA DENGAN PENGHASILAN PALING FANTASTIS
}

\author{
I Gusti Ngurah Agung Dean Krisna \\ gungdeankrisna12@gmail.com
}

\begin{abstract}
Youtube is a video sharing site originating from San Mateo, California, America and is very popular today. Around 100,000 videos are watched every day on Youtube. Every 24 hours there are 65,000 new videos uploaded to Youtube. YouTube has been named the most popular social media for the people of Indonesia. YouTube managed to capture 170 million users or 93.8 percent of the total population of 181.9 million internet users aged 16-64 years. 179.1 million people in Indonesia have used the internet to watch online videos. The large number of YouTube social media enthusiasts makes people who have a lot of creative ideas to make themselves YouTube creators. As for the famous YouTube creators, there are 10 youtubers with the most fantastic income, including Jess No Limit, FrostDiamond, Budi01Gaming, BaimPaula, Rans Entertainment, Deddy Corbuzier, Atta Halilintar, Jessica Jane, Ricis Official, EFDEWE. The purpose of this research is to determine the credibility value of the performance of 10 Indonesian Youtubers with the Most Fantastic Income. The research method used is an expolarative type. The results of this study prove that the highest value of credibility from every YouTube creator is Jessica Jane with a value of 0.0007572 .
\end{abstract}

\begin{abstract}
ABSTRAK
Youtube adalah situs berbagi video yang berasal dari San Mateo, California, Amerika dan sangat populer saat ini. Sekitar 100.000 video ditonton setiap hari di Youtube. Setiap 24 jam ada 65.000 video baru yang diunggah ke Youtube. Youtube dinobatkan sebagai media sosial terpopuler bagi masyarakat Indonesia. YouTube berhasil menjaring 170 juta pengguna atau 93,8 persen dari total populasi 181,9 juta pengguna internet berusia 16-64 tahun. 179,1 juta orang di Indonesia telah menggunakan internet untuk menonton video online. Banyaknya peminat media sosial YouTube membuat orang yang memiliki banyak ide kreatif untuk menjadikan dirinya kreator YouTube. Sedangkan untuk para kreator YouTube ternama, ada 10 youtuber dengan penghasilan paling fantastis, antara lain Jess No Limit, FrostDiamond, Budi01Gaming, BaimPaula, Rans Entertainment, Deddy Corbuzier, Atta Halilintar, Jessica Jane, Ricis Official, EFDEWE. Tujuan dari penelitian ini adalah untuk mengetahui nilai kredibilitas kinerja 10 Youtuber Indonesia dengan Penghasilan Paling Fantastis. Metode penelitian yang digunakan adalah tipe ekspolarisasi. Hasil penelitian ini membuktikan bahwa nilai kredibilitas tertinggi dari setiap kreator YouTube adalah Jessica Jane dengan nilai 0,0007572 .
\end{abstract}

Keyword: Sosial Media Youtube; Video Comment to Subscribe Ratio; Kreadibilitas Comment to Subscribe; 10 Youtuber Indonesia Dengan Penghasilan Terfantastis. 


\section{PENDAHULUAN}

Teknologi informasi dan komunikasi yang telah berkembang dengan pesat mampu menghantarkan manusia untuk menciptakan bentuk baru dalam cara berkomunikasi serta berinteraksi melalui media sosial. Media sosial memberikan pengaruh yang sangat besar untuk manusia dijaman sekarang, saat ini media sosial diajadikan sarana berkomunikasi dalam setiap aktifitas keseharian bersosial di masyarakat. Komunikasi tidak hanya dapat dilakukan secara fisik, tetapi juga dapat dilakukan dengan menggunakan berbagai aplikasi media sosial di dunia maya. Keunggulan layanan aplikasi sosial media salah satunya adalah memberikan ruang komunikasi dua arah antara konsumen-perusahaan dan konsumenkonsumen.

Youtube adalah situs berbagai video yang sangat populer hingga saat ini. "Sekitar 100.000 video ditonton setiap harinya di Youtube. Setiap 24 jam ada 65.000 video baru diunggah ke Youtube. Setiap bulannya Youtube dikunjungi oleh 20 juta penonton dengan mayoritas kisaran usia antara 12 tahun sampai 17 tahun"(Lestari 2013). Youtube memang bukan situs berbagi video pendidikan, namun pada perkembangannya Youtube meluncurkan layanan khusus untuk pendidikan (www.youtube.com/edu) pada tahun 2009. Keuntungan pembelajaran dengan video adalah menghadirkan representasi gambar dan suara dari sebuah gagasan atau peristiwa kepada pembelajar di kelas. Youtube adalah "salah satu layanan berbagi video di internet yang paling populer saat ini" (Program et al., n.d.).

Kehadiran media sosial Youtube membangun kreator-kreator youtube yang memiliki banyak ide-ide yang menarik dan yang terpenting ide kreator youtube selalu ada saja yang membuat penonton untuk selalu menanti video-video terbaru mereka. YouTube dinobatkan sebagai media sosial terpopuler untuk masyarakat Indonesia. YouTube berhasil menjaring 170 juta pengguna atau 93,8 persen dari total keseluruhan populasi 181,9 juta pengguna internet berusia 16-64 tahun. 179,1 juta orang di Indonesia telah memanfaatkan internet untuk menonton video online.

Penelitian ini dilakukan dengan menggunakan metode ekploratif untuk menemukan variabelvariabel yang terdapat pada akun YouTube. Penelitian ini dilakukan dengan tujuan untuk menemukan rasio-rasio yang terdapat pada akun YouTube. Rasio-rasio ini yang nantinya akan digunakan untuk mengukur performa sebuah akun secara matematis. Variabel tersebut yang nantinya akan dibandingkan dan disandingkan untuk diuji relevansinya sehingga menjadi rasio yang relevan. Rasio yang relevan akan digunakan untuk menilai performa 10 akun yang ada pada sosial media YouTube menggunakan Comment to Subscriber Ratio.

\section{TINJAUAN PUSTAKA}

Perkembangan di dalam bidang teknologi pada saat ini sangatlah begitu pesat.Perkembangan yang terjadi dari waktu ke waktu menyebabkan banyaknya platform media sosial yang tersebar di dunia maya serta aplikasi-aplikasiyang di minati masyarakat.Aplikasi yang di minati masyarakat seperti Tiktok,Instagram,Twitter,Whatsaap,dan Youtube.Aplikasi-aplikasi yang bermuculan ini membuat masyarakat menjadi candu.Masyarakat menjadi candu karena di aplikasi tersebut menyuguhkan hiburan-hiburan yang di sukai masyarakat yang di mulai dari anak kecil hingga dewasa.

Dalam perkembangan portofolionya Situs video YouTube telah bekerjasama dengan berbagai intansi swasta maupun pemerintahan, yaitu: (a) July-Agustus 2007 menyelenggarakan siaran bersama dengan CNN acara debat Presiden Amerika; (b) November 2008 menyelenggarakan acara TV episode dan films secara online dengan bekerjasama dengan intansi media swasta di Amerika seperti: Lions Gate, CBS, NBC, Fox, dan Disney; (c) Awal tahun 2009 Situs video 
YouTube melakukan registrasi domain situsnya (www.YouTube-nocookie.com) untuk koleksi videonya yang berada dalam wilayah hukum pemerintah Amerika. Dan pada bulan November meluncurkan siaran pertunjukan bagi para penonton di Inggris yang menampilkan 4000 pertunjukan yang berasal dari 60 pihak ketiga yang bekerjasama dengan YouTube. (d) Pada bulan Maret 2010, YouTube mulai menyiarkan konten tertentu secara gratis, termasuk 60 pertandingan kriket Indian Premier League. Menurut YouTube, ini merupakan siaran acara olahraga besar via Internet pertama di dunia yang bersifat gratis.(Chandra 2018)

YouTube merupakan salah satu penyedia layanan video terbesar saat ini, YouTube juga media untuk upload secara gratis. Para pengguna dapat memuat, menonton, dan berbagi klip video secara gratis. YouTube juga sangat cocok bagi kita yang ingin mencari informasi tanpa harus membaca artikel, Umumnya video-video di YouTube adalah klip video klip, Acara TV, Film serta video buatan para penggunanya sendiri.(Mangole, Himpong, and Kalesaran 2017)

kompatibel. Hal itu membuat pembuat video amatir dapat dengan bebas mengunggah kontenkonten video mereka untuk dipublikasikan. Jika video mereka mendapat sambutan baik, jumlah viewers akan bertambah. Viewers banyak akan mengundang pengiklan untuk memasang iklan dalam video-video mereka selanjutnya. Senada dengan televisi, konten program televisi yang disukai masyarakat, dalam hal ini ratingnya tinggi, akan menarik pengiklan secara otomatis. Video.(David, Sondakh, and Harilama 2017)

Youtube memiliki pengaruh yang sangat kuat dalam lingkungan industri,sehingga youtube menciptakan konten-konten kreator yang memiliki kemampuan untuk menarik antusias masyarakat untuk melihat hasil konten yang mereka buat. Kredibilitas dari sebuah akun sangat penting karena berpengaruh terhadap akursi dan objektifitas berita yang disampaikan kepada publik. Kredibilitas dibentuk ketika seseorang yang mengelola akun YouTube tersebut memiliki sumber pengetahuan yang cukup, keterampilan, dan kepercayaan diri sehingga menghasilkan sebuah konten yang memiliki performa yang baik [8]. Kredibilitas sebuah akun dapat diukur dari performa akun yang harus diukur secara sistematis. Dalam mengukur performa dari sebuah akun diperlukan skala pengukuran yang akan tertuang kedalam rasio-rasio.(Permana 2021) 


\section{METODE PENELITIAN}

Penelitian saat ini menggunakan metode yang bertipe eksploratif yang gunanya untuk meneliti seluruh kategori masyarakat yang menggunakan media sosial Youtube dengan tujuan memperdalam pengetahuan dan mencari ide-ide yang baru.Penelian ini bisa di gunakan sebagai acuan penelitian kuantitatif,sehingga suatu objek yang di analisis memiliki nilai berupa angka yang bisa di dihitung dalam memformulasikan sebagai rasio.(Hendika Permana 2021)

Tujuan dari penelitian ini untuk mengetahui nilai kerdibillitas dari performa 10 Youtuber Indonesia Dengan Penghasilan Paling Fantastis.Ada beberapa langkah yang harus di lakukan guna untuk mendapatkan peringkat pertama akun youtube dengan penghasilan terfantastis dengan memiliki performa terbaik di indonesia.Langkah-langkah yang harus di lakukan seperti:

1. Melakukan Eksplorasi pada website untuk menentukan objek yang di analisa.

Eksplorasi ini dilakukan di beberapa halaman website yang menyediakan banyak informasi tentang objek yang ingin di teliti. Setelah eksplorasi yang dilakukan sudah menemukan 10 Youtuber Indonesia Dengan Penghasilan Paling Fantastis yang akan dijadikan objek analisa.Eksplorasi yang sudah dilakukan di halaman website sudah di lakukan maka selanjutnya mencari nama-nama youtuber yang sudah di tentukan dan harus dipastikan youtuber itu memiliki media sosial Youtube.

\section{Menghitung Nilai Rata-Rata Variabel dari 10 Youtuber Indonesia Dengan Penghasilan Paling Fantastis.}

Untuk langkah ini,saatnya peneliti melakukan penghitungan terhadap variabel Comment dan Subscribe. variabel adalah segala sesuatu yang berbentuk apa saja yang ditetapkan oleh peneliti untuk dipelajari sehingga diperoleh informasi tentang hal tersebut, kemudian ditarik kesimpulannya(Purwanto 2019).Nilai rata-rata dari variabel comment dan variabel subscribe dapat di cari dengan cara mengambil minimal 10 postingan video dan dijumlahkan untuk menemukan nilai rata-rata dari masing-masing variabel.

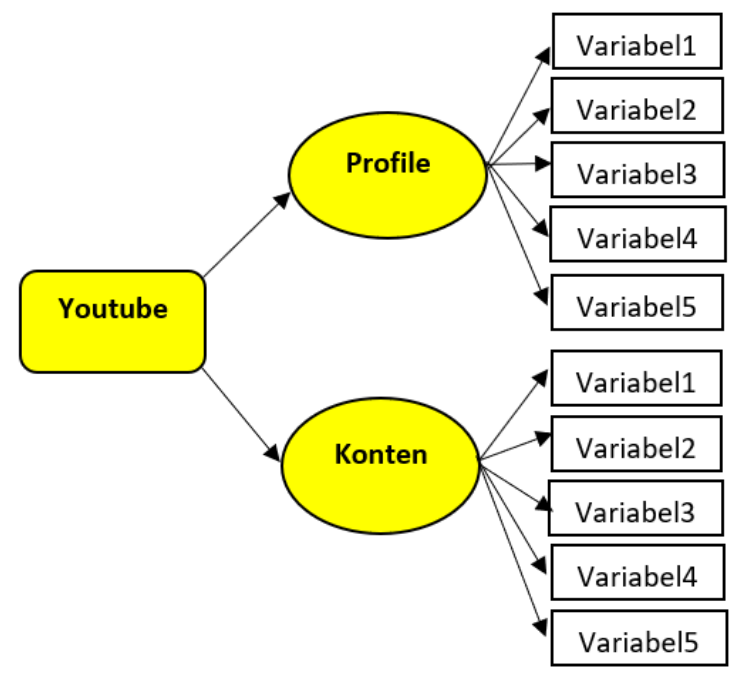

Gambar 1. Analisa Nilai Rata-Rata Variabel 


\section{Menghitung Nilai Kredibilitas Rasio.}

Untuk menghitung nilai kreadibilitas dari comment to subscribe ratio,peneliti menggunakan cara membagi nilai variabel comment dan variabel subscribe.Jika comment memiliki nilai 2,492 dan subscribe $23,400,000$,maka cara menghitungnya $2,492: 23,400,000=0,000106496$. Dengan demikian nilai ratio dari comment to subscribe ratio 0,000106496 .

\section{Menentukan Peringkat Dari 10 Youtuber Indonesia Dengan Penghasilan Paling Fantastis .}

Langkah ini merupakan langkah terakhir yang di lakukan pada penelitian ini yaitu menentukan peringkat. Pada menentukan peringkat perlu melihat karakteristik dari setiap ratio yang di teliti.Jika karakteristik dari ratio tersebut rendah akan mendapatkan nilai 5 dan jika tinggi akan mendapatkan nilai 1.Jika karakteristik tingg maka yang mendapatkan nilai tinggi akan mendapatkan peringkat 5 dan yang rendah akan mendapatkan nilai 1 . 


\section{HASIL DAN PEMBAHASAN}

10 Youtuber Indonesia Dengan Penghasilan Paling Fantastis,diantranya :

1) Jess No Limit

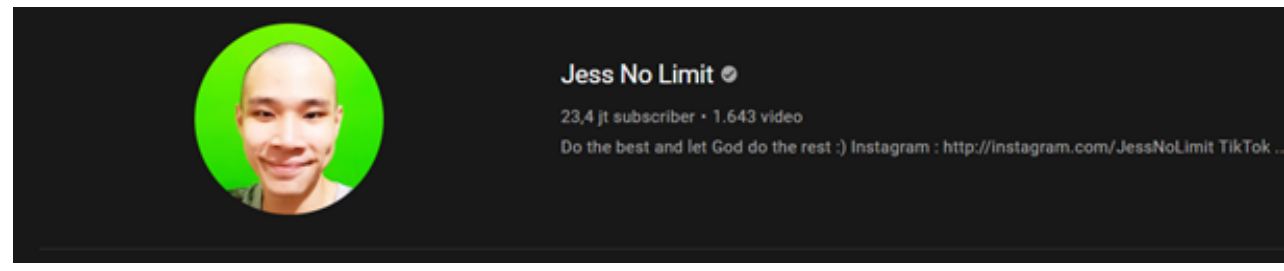

Gambar 1. Youtuber Jess No Limit

Sumber: https://www.youtube.com/c/JessNoLimit (Akses Pada 19/10/21)

2) Frost Diamond

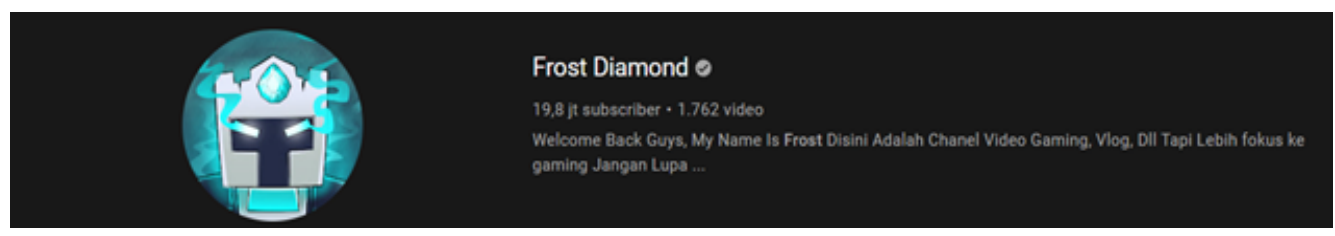

Gambar 2. Youtuber Frost Diamond

Sumber: https://www.youtube.com/c/KanandaWidyantara (Akses Pada 19/10/21)

3) BUDI01 GAMING

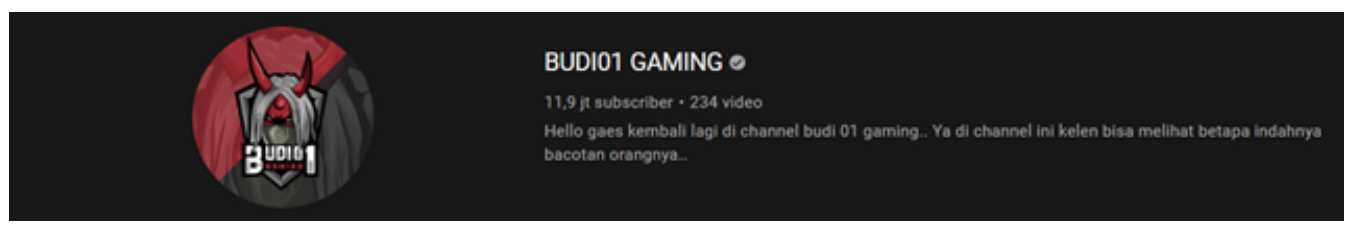

Gambar 3. Yotuber BUDI01 GAMING

Sumber: https://www.youtube.com/c/BUDI01GAMING (Akses Pada 19/10/21)

4) BAIM PAULA

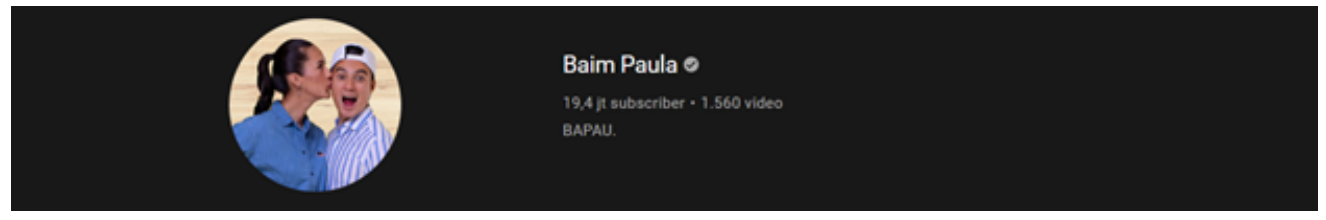

Gambar 4. Youtuber Baim Paula

Sumber: https://www.youtube.com/c/BaimPaula (Akses Pada 19/10/21) 
5) Rans Entertainment

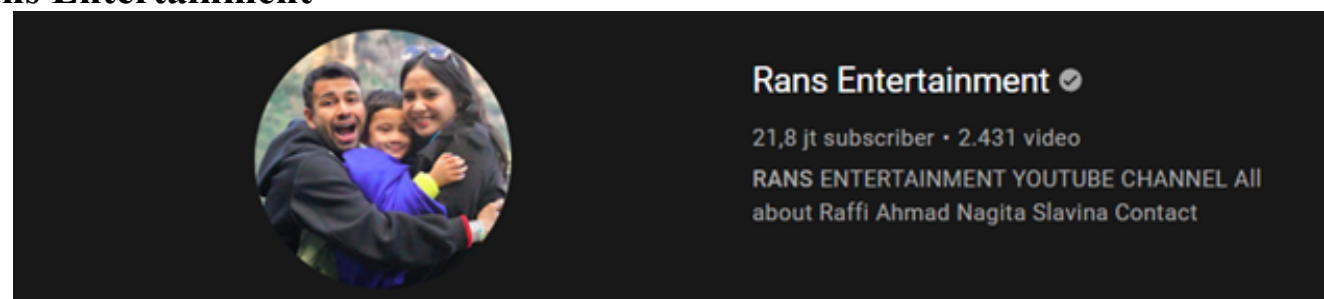

Gambar 5. Youtuber Rans Entertainment

Sumber: https://www.youtube.com/c/RansEntertainment (Akses Pada 19/10/21)

6) DEDDY CORBUZIER

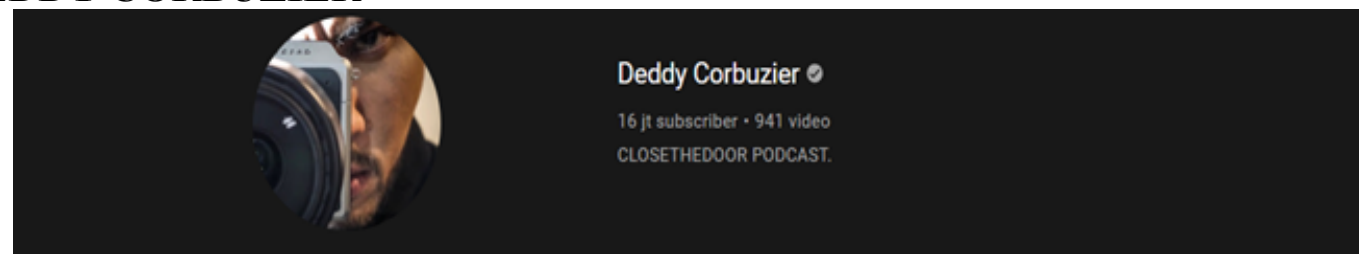

Gambar 6. Youtuber Deddy Corbuzier

Sumber: https://www.youtube.com/c/corbuzier (Akses Pada 19/10/21)

7) ATTA HALILINTAR

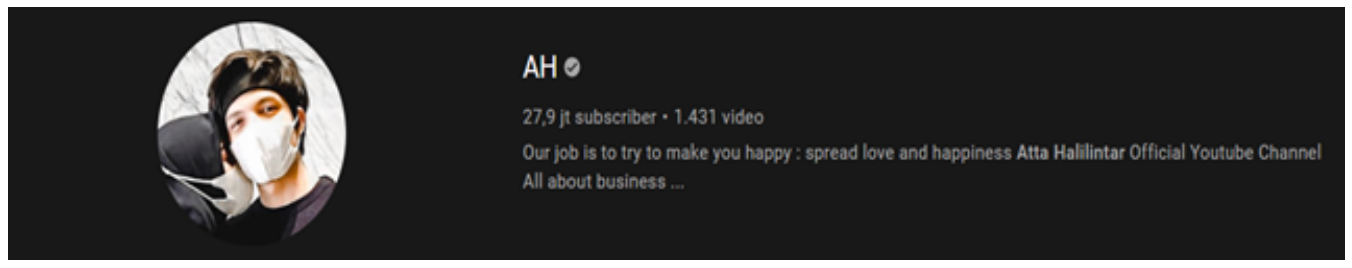

Gambar 7. Youtuber Atta Halilintar

Sumber: https://www.youtube.com/c/AttaHalilintar (Akses Pada 19/10/21)

8) JESSICA JANE

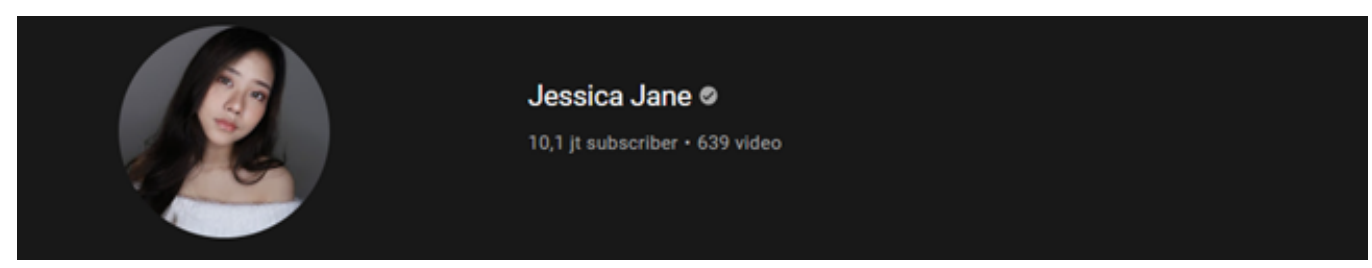

Gambar 8. Youtuber JESSICA JANE

Sumber: https://www.youtube.com/c/JessicaJane99 (Akses Pada 19/10/21) 


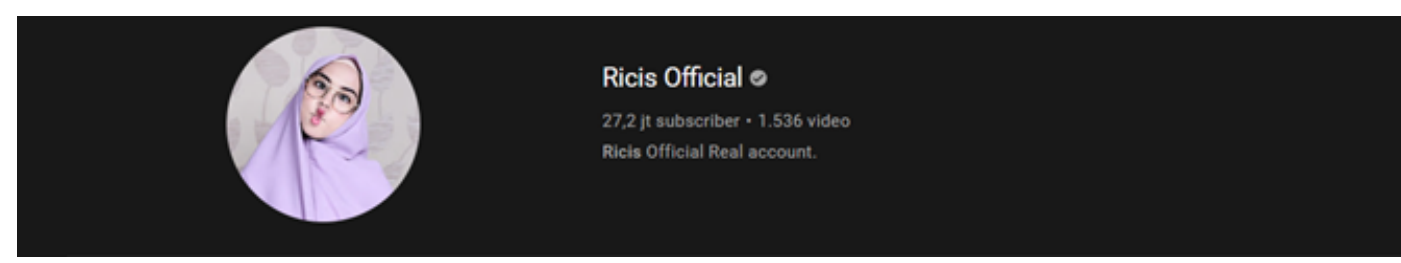

Gambar 9. Youtuber Ricis Official

Sumber: https://www.youtube.com/c/Ricisofficial1795(Akses Pada 19/10/21)

10)

\section{EFDEWE}

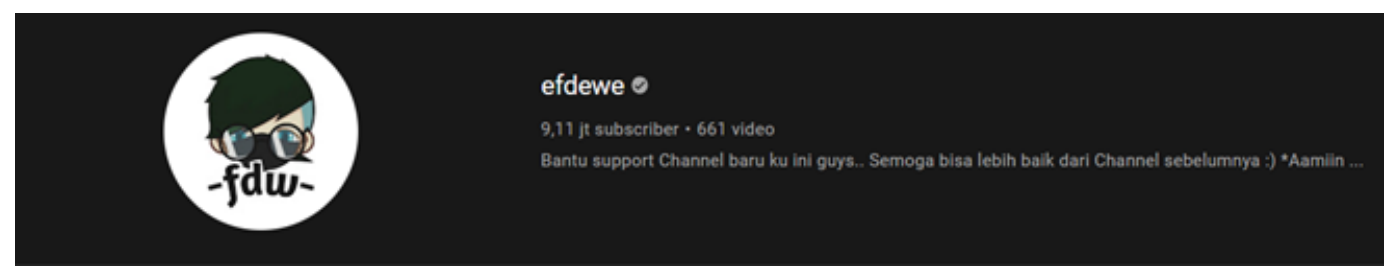

Gambar 10. Youtuber EFDEWE

Sumber: https://www.youtube.com/c/efdewe (Akses Pada 19/10/21)

Dari ke-10 10 Youtuber Indonesia Dengan Penghasilan Paling Fantastis, peneliti menemukan nilai dari masing-masing variabel yang ada untuk menghitung rasio Comments to Subscribe dari setiap akun. Pada akun TikTok terdapat 6 variabel, diantaranya yaitu :

1. Subscribe

2. Video Likes

3. Video Dislike

4. Video Comments

5. Video Share

6. Video view

Dari Ke-6 variabel tersebut peneliti hanya fokus untuk menemukan hasil dari 2 variabel,yaitu:

1. Subscribe

2. Video Comments

Dari kedua variabel tersebut kemudian dianalisa sehingga menemukan nilai rata-rata dari variabel video comments dan Subsriber. Untuk menghitung nilai rata-rata dari variabel video comments dan variabel Subsriber yaitu dengan cara mengambil minimal 10 postingan kemudian di hitung sehingga menemukan nilai rata-rata dari masing-masing variabel. Berikut merupakan tabel nilai rata-rata dari masing-masing Youtuber di Indonesia, yaitu : 
Tabel 1. Analisa Nilai Rata-Rata Nilai Variabel Video Comments dan Subsriber Youtuber Jess No Limit

\begin{tabular}{|c|c|c|}
\hline NO & COMMENTS & SUBSCRIBER \\
\hline 1 & 2.081 & $23,400,000$ \\
\hline 2 & 3.650 & $23,400,000$ \\
\hline 3 & 2.270 & $23,400,000$ \\
\hline 4 & 1.743 & $23,400,000$ \\
\hline 5 & 1.730 & $23,400,000$ \\
\hline 6 & 2.362 & $23,400,000$ \\
\hline 7 & 2.782 & $23,400,000$ \\
\hline 8 & 2.896 & $23,400,000$ \\
\hline 9 & 2.873 & $23,400,000$ \\
\hline 10 & 2.537 & $23,400,000$ \\
\hline TOTAL & $\mathbf{2 . 4 9 2}$ & $\mathbf{2 3 , 4 0 0 , 0 0 0}$ \\
\hline
\end{tabular}

Sumber: Pengolah Data Excel

Tabel 2. Analisa Nilai Rata-Rata Nilai Variabel Video Comments dan Subsriber Youtuber Frost Diamond

\begin{tabular}{|c|c|c|}
\hline NO & COMMENTS & SUBSCRIBER \\
\hline 1 & 1.065 & $19,700,000$ \\
\hline 2 & 2.483 & $19,700,000$ \\
\hline 3 & 2.595 & $19,700,000$ \\
\hline 4 & 2.348 & $19,700,000$ \\
\hline 5 & 2.330 & $19,700,000$ \\
\hline 6 & 3.353 & $19,700,000$ \\
\hline 7 & 2.782 & $19,700,000$ \\
\hline 8 & 2.483 & $19,700,000$ \\
\hline 9 & 2.081 & $19,700,000$ \\
\hline 10 & 4.122 & $19,700,000$ \\
\hline TOTAL & $\mathbf{2 . 5 6 4}$ & $\mathbf{1 9 , 7 0 0 , 0 0 0}$ \\
\hline
\end{tabular}

Sumber: Pengolah Data Excel 
Tabel 3. Analisa Nilai Rata-Rata Nilai Variabel Video Comments dan Subsriber Youtuber BUDI01 GAMING

\begin{tabular}{|c|c|c|}
\hline NO & COMMENTS & SUBSCRIBER \\
\hline 1 & 6.611 & $11,900,000$ \\
\hline 2 & 6.713 & $11,900,000$ \\
\hline 3 & 7.145 & $11,900,000$ \\
\hline 4 & 8.849 & $11,900,000$ \\
\hline 5 & 10.363 & $11,900,000$ \\
\hline 6 & 5.958 & $11,900,000$ \\
\hline 7 & 6.713 & $11,900,000$ \\
\hline 8 & 9.021 & $11,900,000$ \\
\hline 9 & 8.236 & $11,900,000$ \\
\hline 10 & 9.937 & $11,900,000$ \\
\hline TOTAL & $\mathbf{7 . 9 5 5}$ & $\mathbf{1 1 , 9 0 0 , 0 0 0}$ \\
\hline
\end{tabular}

Sumber: Pengolah Data Excel

Tabel 4. Analisa Nilai Rata-Rata Nilai Variabel Video Comments dan Subsriber Youtuber BAIM PAULA

\begin{tabular}{|c|c|c|}
\hline NO & COMMENTS & SUBSCRIBER \\
\hline 1 & 12.725 & $19,600,000$ \\
\hline 2 & 5.900 & $19,600,000$ \\
\hline 3 & 9.954 & $19,600,000$ \\
\hline 4 & 5.428 & $19,600,000$ \\
\hline 5 & 27.698 & $19,600,000$ \\
\hline 6 & 1.194 & $19,600,000$ \\
\hline 7 & 2.550 & $19,600,000$ \\
\hline 8 & 1.122 & $19,600,000$ \\
\hline 9 & 1.188 & $19,600,000$ \\
\hline 10 & 1.852 & $19,600,000$ \\
\hline TOTAL & $\mathbf{6 . 9 6 1}$ & $\mathbf{1 9 , 6 0 0 , 0 0 0}$ \\
\hline
\end{tabular}

Sumber: Pengolah Data Excel

Tabel 5. Analisa Nilai Rata-Rata Nilai Variabel Video Comments dan Subsriber Youtuber Rans Entertainment

\begin{tabular}{|c|c|c|}
\hline NO & COMMENTS & SUBSCRIBER \\
\hline 1 & 1.370 & $21,800,000$ \\
\hline 2 & 643 & $21,800,000$ \\
\hline 3 & 1.223 & $21,800,000$ \\
\hline 4 & 1.296 & $21,800,000$ \\
\hline 5 & 4.674 & $21,800,000$ \\
\hline 6 & 1.361 & $21,800,000$ \\
\hline 7 & 654 & $21,800,000$ \\
\hline 8 & 820 & $21,800,000$ \\
\hline 9 & 23.382 & $21,800,000$ \\
\hline 10 & 2.685 & $21,800,000$ \\
\hline TOTAL & $\mathbf{3 . 8 1 1}$ & $\mathbf{2 1 , 8 0 0 , 0 0 0}$ \\
\hline
\end{tabular}


Sumber: Pengolah Data Excel

Tabel 6. Analisa Nilai Rata-Rata Nilai Variabel Video Comments dan Subsriber Youtuber Deddy Corbuzier

\begin{tabular}{|c|c|c|}
\hline NO & COMMENTS & SUBSCRIBER \\
\hline 1 & 4.851 & $15,900,000$ \\
\hline 2 & 6.120 & $15,900,000$ \\
\hline 3 & 13.268 & $15,900,000$ \\
\hline 4 & 6.899 & $15,900,000$ \\
\hline 5 & 8.493 & $15,900,000$ \\
\hline 6 & 5.331 & $15,900,000$ \\
\hline 7 & 11.866 & $15,900,000$ \\
\hline 8 & 52.865 & $15,900,000$ \\
\hline 9 & 5.373 & $15,900,000$ \\
\hline 10 & 57.079 & $15,900,000$ \\
\hline TOTAL & $\mathbf{2 0 . 9 1 6}$ & $\mathbf{1 5 , 9 0 0 , 0 0 0}$ \\
\hline
\end{tabular}

Sumber: Pengolah Data Excel

Tabel 7. Analisa Nilai Rata-Rata Nilai Variabel Video Comments dan Subsriber Youtuber Atta Halilintar

\begin{tabular}{|c|c|c|}
\hline NO & COMMENTS & SUBSCRIBER \\
\hline 1 & 2.365 & $27,900,000$ \\
\hline 2 & 2.186 & $27,900,000$ \\
\hline 3 & 4.753 & $27,900,000$ \\
\hline 4 & 5.974 & $27,900,000$ \\
\hline 5 & 5.917 & $27,900,000$ \\
\hline 6 & 4.817 & $27,900,000$ \\
\hline 7 & 5.666 & $27,900,000$ \\
\hline 8 & 3.056 & $27,900,000$ \\
\hline 9 & 4.690 & $27,900,000$ \\
\hline 10 & 4.130 & $27,900,000$ \\
\hline TOTAL & $\mathbf{4 . 5 5 5}$ & $\mathbf{2 7 , 9 0 0 , 0 0 0}$ \\
\hline
\end{tabular}

Sumber: Pengolah Data Excel

Tabel 8. Analisa Nilai Rata-Rata Nilai Variabel Video Comments dan Subsriber Youtuber Jessica Jane

\begin{tabular}{|c|c|c|}
\hline NO & COMMENTS & SUBSCRIBER \\
\hline 1 & 3.348 & 10.000 .000 \\
\hline 2 & 2.862 & 10.000 .000 \\
\hline 3 & 6.417 & 10.000 .000 \\
\hline 4 & 6.499 & 10.000 .000 \\
\hline 5 & 19.098 & 10.000 .000 \\
\hline 6 & 9.113 & 10.000 .000 \\
\hline 7 & 18.191 & 10.000 .000 \\
\hline 8 & 5.621 & 10.000 .000 \\
\hline 9 & 2.501 & 10.000 .000 \\
\hline 10 & 2.065 & 10.000 .000 \\
\hline TOTAL & $\mathbf{7 . 5 7 2}$ & $\mathbf{1 0 , 0 0 0 , 0 0 0}$ \\
\hline
\end{tabular}


Sumber: Pengolah Data Excel

Tabel 9. Analisa Nilai Rata-Rata Nilai Variabel Video Comments dan Subsriber Youtuber Ricis Official

\begin{tabular}{|c|c|c|}
\hline NO & COMMENTS & SUBSCRIBER \\
\hline 1 & 6.965 & $27,100,000$ \\
\hline 2 & 6.645 & $27,100,000$ \\
\hline 3 & 10.053 & $27,100,000$ \\
\hline 4 & 6.871 & $27,100,000$ \\
\hline 5 & 5.199 & $27,100,000$ \\
\hline 6 & 6.264 & $27,100,000$ \\
\hline 7 & 11.939 & $27,100,000$ \\
\hline 8 & 10.916 & $27,100,000$ \\
\hline 9 & 26.584 & $27,100,000$ \\
\hline 10 & 11.673 & $27,100,000$ \\
\hline TOTAL & $\mathbf{1 0 . 3 1 1}$ & $\mathbf{2 7 , 1 0 0 , 0 0 0}$ \\
\hline
\end{tabular}

Sumber: Pengolah Data Excel

Tabel 10. Analisa Nilai Rata-Rata Nilai Variabel Video Comments dan Subsriber Youtuber EFDEWE

\begin{tabular}{|c|c|c|}
\hline NO & COMMENTS & SUBSCRIBER \\
\hline 1 & 1.792 & $9,009,000$ \\
\hline 2 & 3.497 & $9,009,000$ \\
\hline 3 & 2.762 & $9,009,000$ \\
\hline 4 & 2.776 & $9,009,000$ \\
\hline 5 & 1.356 & $9,009,000$ \\
\hline 6 & 2.349 & $9,009,000$ \\
\hline 7 & 2.406 & $9,009,000$ \\
\hline 8 & 1.787 & $9,009,000$ \\
\hline 9 & 6.242 & $9,009,000$ \\
\hline 10 & 2.895 & $9,009,000$ \\
\hline TOTAL & $\mathbf{2 . 3 4 1}$ & $\mathbf{9 , 0 0 9 , 0 0 0}$ \\
\hline
\end{tabular}

Sumber: Pengolah Data Excel 
Setelah menghitung nilai rata-rata tersebut,akan menemukan hasil akhir nilai rata-rata dari variabel Video Comment dan Subscriber.

Tabel 11. Nilai Variabel Pada 10 Youtuber Indonesia Dengan Penghasilan Paling Fantastis

\begin{tabular}{|l|c|c|c|c|c|}
\hline Variable & $\begin{array}{c}\text { Jess no } \\
\text { Limit }\end{array}$ & $\begin{array}{c}\text { Frost } \\
\text { Diamond }\end{array}$ & $\begin{array}{c}\text { Budi01 } \\
\text { Gaming }\end{array}$ & $\begin{array}{c}\text { Baim } \\
\text { Paula }\end{array}$ & $\begin{array}{c}\text { Rans } \\
\text { Entertainment }\end{array}$ \\
\hline Comment & 2,492 & 2,564 & 7,955 & 6,961 & 3,811 \\
\hline Subscribe & $23,400,000$ & $19,700,000$ & $11,900,000$ & $19,600,000$ & $21,800,000$ \\
\hline Variable & $\begin{array}{c}\text { Deddy } \\
\text { Corbuzier }\end{array}$ & $\begin{array}{c}\text { Atta } \\
\text { Halilintar }\end{array}$ & $\begin{array}{c}\text { Jessica } \\
\text { Jane }\end{array}$ & $\begin{array}{c}\text { Ricis } \\
\text { Official }\end{array}$ & Efdewe \\
\hline Comment & 20,916 & 4,555 & 7,572 & 10,311 & 2,341 \\
\hline Subscribe & $15,900,000$ & $27,900,000$ & $10,000,000$ & $27,100,000$ & $9,009,000$ \\
\hline
\end{tabular}

Sumber: Pengolahan Data Excel

Pada penelitian ini hanya berfokus untuk menghitung Video Comments to subscriber.Untuk menghitung Kredibilitas dari masing-masing youtuber,peneliti menghitung dengan cara variabel 1 akan dibagi dengan variabel 2,sehingga akan di temukan hasil analisis dari rasio tersebut.

Tabel 12. Hasil Perhitungan Rasio

\begin{tabular}{|c|c|c|c|c|c|}
\hline Ratio & $\begin{array}{c}\text { Jess no } \\
\text { Limit }\end{array}$ & $\begin{array}{c}\text { Frost } \\
\text { Diamond }\end{array}$ & $\begin{array}{l}\text { Budi01 } \\
\text { Gaming }\end{array}$ & $\begin{array}{c}\text { Baim } \\
\text { Paula }\end{array}$ & $\begin{array}{c}\text { Rans } \\
\text { Entertainment }\end{array}$ \\
\hline $\begin{array}{c}\text { Video Comment } \\
\text { to Subscribe Ratio }\end{array}$ & 0,000106496 & 0,000130152 & 0,000668487 & 0,000355153 & 0,000174817 \\
\hline Variable & $\begin{array}{c}\text { Deddy } \\
\text { Corbuzier }\end{array}$ & $\begin{array}{c}\text { Atta } \\
\text { Halilintar }\end{array}$ & $\begin{array}{c}\text { Jessica } \\
\text { Jane }\end{array}$ & $\begin{array}{c}\text { Ricis } \\
\text { Official }\end{array}$ & Efdewe \\
\hline $\begin{array}{c}\text { Video Comment } \\
\text { to Subscribe Ratio }\end{array}$ & 0,001315472 & 0,000163262 & 0,0007572 & 0,00038048 & 0,000259851 \\
\hline
\end{tabular}

Sumber: Pengolahan Data Excel

Video Comments to Subsriber Ratio memiliki karakteristik yang tinggi, artinya semakin tinggi nilai yang dihasilkan maka semakin baik kredibilitas dari performa akun tersebut. Untuk memberikan peringkat pada masing-masing Youtuber, peneliti memberikan angka 10 kepada Youtuber yang mendapatkan nilai tertinggi dan angka 1 untuk Youtuber yang mendapatkan nilai terendah. Berikut merupakan tabel urutan nilai yang dihasilkan oleh masing-masing Youtuber. 
Tabel 13. Nilai Rasio Pada 10 Youtuber Indonesia Dengan Penghasilan Paling Fantastis

\begin{tabular}{|c|c|c|c|c|c|}
\hline Ratio & $\begin{array}{c}\text { Jess no } \\
\text { Limit }\end{array}$ & $\begin{array}{c}\text { Frost } \\
\text { Diamond }\end{array}$ & $\begin{array}{c}\text { Budi01 } \\
\text { Gaming }\end{array}$ & $\begin{array}{c}\text { Baim } \\
\text { Paula }\end{array}$ & $\begin{array}{c}\text { Rans } \\
\text { Entertainment }\end{array}$ \\
\hline Nilai & 9 & 8 & 2 & 4 & 6 \\
\hline Variable & $\begin{array}{c}\text { Deddy } \\
\text { Corbuzier }\end{array}$ & $\begin{array}{c}\text { Atta } \\
\text { Halilintar }\end{array}$ & $\begin{array}{c}\text { Jessica } \\
\text { Jane }\end{array}$ & $\begin{array}{c}\text { Ricis } \\
\text { Official }\end{array}$ & Efdewe \\
\hline Nilai & 1 & 7 & 10 & 3 & 5 \\
\hline
\end{tabular}

Sumber: Pengolahan Data Excel

Dari Tabel Nilai Rasio 10 Youtuber Indonesia Dengan Penghasilan Paling Fantastis dapat simpulkan bahwa Jesica Jane mendapatkan nilai tertinggi untuk rasio Video Comments to Subscribe. Sedangkan Youtuber Deddy Corbuzier mendapatkan nilai terendah untuk rasio ini. Jadi, pada penelitian ini Jesica Jane memiliki kredibilitas performa yang lebih baik dibandingkan dengan Youtuber Indonesia yang lainnya.

\section{KESIMPULAN}

Tujuan dari penelitian ini adalah mengetahui kredibilitas performa dari 10 Youtuber Indonesia Dengan Penghasilan Paling Fantastis menggunakan Video Comments to Subscribe. 10 Youtuber Indonesia Dengan Penghasilan Paling Fantastis diantaranya Jess No Limit, Frost Diamond,Budi01Gaming,BaimPaula,RansEntertainment,DeddyCorbuzier,Atta Halilintar,JessicaJane,RicisOfficial,Efdewe.Dari Ke-10 Youtuber Indonesia Dengan Penghasilan Paling Fantastis daapat disimpulkan bahwa:

1. Peringkat pertama diraih oleh Jessica Jane dengan nilai tertinggi 0,0007572

2. Peringkat kedua diraih oleh Jess No Limit dengan nilai 0,000106496

3. Peringkat ketiga diraih oleh Frost Diamond dengan nilai 0,000130152

4. Peringkat keempat diraih oleh Atta Halilintar dengan nilai 0,000163262

5. Peringkat kelima diraih oleh Rans Entertainment dengan nilai 0,000174817

6. Peringkat keenam diraih oleh Efdewe dengan nilai 0,000259851

7. Peringkat ketujuh diraih oleh Baim Paula dengan nilai 0,000355153

8. Peringkat kedelapan diraih oleh Ricis Official dengan nilai 0,00038048

9. Peringkat kesembilan diraih oleh Budi01Gaming dengan nilai 0,000668487

10. Peringkat kesepuluh diraih oleh Deddy Corbuzier dengan nilai 0,001315472 


\section{DAFTAR PUSTAKA}

Chandra, Edy. 2018. "Youtube, Citra Media Informasi Interaktif Atau Media Penyampaian Aspirasi Pribadi." Jurnal Muara Ilmu Sosial, Humaniora, Dan

Seni 1 (2): 406. https://doi.org/10.24912/jmishumsen.v1i2.1035.

David, Eribka, Mariam Sondakh, and Stefi Harilama. 2017. "Pengaruh Konten Vlog Dalam Youtube Terhadap Pembentukan Sikap Mahasiswa Ilmu Komunikasi." Acta Diurna 6 (1). https://ejournal.unsrat.ac.id/index.php/index/index.

Hendika Permana, I Putu. 2021. "Analisis Rasio Pada Akun Youtube Untuk Penelitian Kualitatif Menggunakan Metode Ekploratif." Jurnal Ilmiah Media Sisfo 15 (1): 40. https://doi.org/10.33998/mediasisfo.2021.15.1.970.

Lestari, Renda. 2013. "Penggunaan Youtube Sebagai Media Pembelajaran Bahasa Inggris." Seminar Nasional Kedua Pendidikan Berkemajuan Dan Menggembirakan (The Second Progressive and Fun Education Seminar), 607-12.

https://publikasiilmiah.ums.ac.id/bitstream/handle/11617/9566/68.pdf?sequence $=1 \&$ isAllowed $=\mathrm{y}$.

Mangole, Kevin David B., Meity Himpong, and Edmon R. Kalesaran. 2017. "Pemanfaatan Youtube Dalam Meningkatkan Pengetahuan Masyarakat Di Desa Paslaten Kecamatan Remboken Minahasa." Jurnal Acta Diurna 6 (4): 1-15. https://ejournal.unsrat.ac.id/index.php/actadiurnakomunikasi/article/download/1 $8359 / 17887$.

Permana, I Putu Hendika. 2021. "Analisis Rasio Pada Akun Youtube Untuk Penelitian Kualitatif Menggunakan Metode Ekploratif." Jurnal Ilmiah Media Sisfo 15 (1): 40-48. https://doi.org/10.33998/MEDIASISFO.2021.15.1.970.

Program, Dosen, Studi Pendidikan, Bahasa Inggris, Universitas Sanata Dharma, Alamat Pbi, Jl Affandi, and Mrican Tromolpos. n.d. "FX . Ouda Teda Ena Tantangan Dunia Pendidikan Dalam Memenuhi Kebutuhan Generasi Internet Cukup Besar . Salah Satu Karakter Yang Penting Dari Generasi Internet Adalah Kemauan Mereka Yang Tinggi Untuk Belajar . Namun Demikian Mereka Belajar Secara Berbeda D," 1-10.

Purwanto, Nfn. 2019. "Variabel Dalam Penelitian Pendidikan.” Jurnal Teknodik 6115: 196-215. https://doi.org/10.32550/teknodik.v0i0.554. 